ARTICLE

Received 20 Aug 2016 | Accepted 28 Nov 2016 | Published 20 Dec 2016

DOI: 10.1057 /palcomms.2016.101

\title{
"They never talk about a victim's feelings: according to criminal law, feelings are not facts"- Portuguese judicial narratives about sex crimes
}

\author{
Isabel Ventura ${ }^{1}$
}

\begin{abstract}
Sexual violence is a central dimension of what is generally called violence against women. Historically, the law has been one of the structures that has reinforced gender inequality and legitimized male seizure of women's sexuality within and outside marriage: legally, married women had no right to sexual freedom regarding their husbands and, at the same time, non-wed women who pressed charges against white men were accused of lying and faced victim-blaming judicial practices. Since the beginning of the 1990s, Portuguese rape legislation has changed in order to recognize that sex crimes offend someone's right to sexual self-determination. The Criminal Code has abandoned expressions like modesty and decency when referring to sex crimes, and a controversial mitigating penalty norm based on a victim's provocative behaviour or on the relation between the accused and the plaintiff was repealed in 1995. In addition, criminal law has evolved to a gender-neutral formulation and expanded the definition of rape adopting the "all penetration" formula. Nevertheless, the discourses of Portuguese jurisprudence and doctrine reveal stereotyped images about rape victims' behaviour and biased evaluations against women. Therefore, the 'law in books' must be analysed in its relation with 'law in action', which is unescapably influenced by doctrine and by magistrates' individual beliefs. This paper aims to capture judicial representations of rape, rape victims and offenders. Qualitative data are used based on 20 semi-structured interviews with 18 judges and prosecutors and two attorneys. The interviews were analysed through critical discourse analysis using a feminist approach. This article is published as part of a collection on gender studies.
\end{abstract}

\footnotetext{
${ }^{1}$ University of Minho, Braga, Portugal Correspondence: (e-mail: isabel.ventura.pt@gmail.com)
} 


\section{Introduction}

ince the Middle Ages the idea that the "exercise of power lies in the law" has been accepted (Foucault, 1976). From Cannon to Roman law or to the Napoleonic Code, legal norms established rules that produced and reinforced social inequalities, which served the elites' interests. Criminal penalties differed depending on the legal classification of people, their social status, gender and religious beliefs. Slaves had few or no rights at all and as they were legally considered property their owners were legally allowed to rape them facing no punishment. Interreligious and interclass marriages were forbidden or discouraged and, for centuries, rape against prostituted women was not a crime. The legal classification of western women was based on their sexual experience, age, marital status and social class. Rape was considered a crime against the honesty and decency of a woman, which affected her family's honour (Brownmiller, 1975; Vigarello, 1998; Bourke, 2007). As claimed by legal discourses, the ultimate goal of a woman was to find a husband (Beleza, 1990) to whom she would only have access as long as her sexual behaviour was considered decent. Raped single women were encouraged to marry their rapists, since they could not expect to get a good matrimony (or to marry at all) after losing their virginity. For rapists, marrying their victims ceased legal process.

The connections between law and female subjugation have been the subject of critical feminist perspectives that uncovered male violence legal tolerance (Mackinnon, 1989; Beleza, 1990; Walby, 1990; Kennedy, 1993; Sottomayor, 2011; Pandey, 2014). Sylvia Walby identifies six key structures through which women are socially, economically, culturally and sexually subjugated. Two of the key structures that help maintaining male domination are sexuality and violence (Walby, 1990). Walby also argues that, during the 20th century, patriarchy has changed from private (under the authority of the head of the household) to public in nature. The author claims that, despite the fact that women have gained access to the public sphere and their condition has ameliorated, this improvement has not been translated into universal access to justice, given the structures that maintain the State's compliance with women's subordination. One of those structures is the State's principle of minimum intervention (only intervening in the most extreme cases) and the promotion of judicial practices that discourage victims and limit women's access to justice. Law and the judicial system represent one of the structures of symbolic power that gives meaning(s) to what is "the masculine" and to what is "the feminine". In this process, it produces hierarchical knowledge that establishes the masculine as the universal subject and the feminine as "otherness" (Beauvoir, 1949; Jackson, 1984). Those categories are constructed from scientific discourses and other social practices that are frequently conflicting. Therefore, the sexed body becomes a field of signification where different and clashing mechanisms of power interpose (Haraway, 1991; Potts, 2002).

Since the ground-breaking work by Brownmiller, Against our will (1975), rape became central to feminists' analysis (Griffin, 1971; Russel, 1975, 1982; Marcus, 1992; Fuller, 1995; Smart, 1995; Lees, 1996, 1997; Figueiredo, 1998; Gavey, 1999, 2005; Bevacqua, 2000; Helliwell, 2000; Mardorossian, 2002, 2014; Watson-Franke, 2002; Bourke, 2007; Toit, 2009) and particularly to feminist jurisprudence (Pateman, 1980; Chamallas, 1988; Mackinnon, 1989, 2003, 2016; Pineau, 1989; Beleza, 1990, 1994, 1995, 1996,; Henderson, 1992; Lees, 1996, 1997; Cowan, 2007; Faedi, 2009; Sottomayor, 2011). Feminist scholarship debunked the myth of the "rape by a stranger in a solitary alley" (Burt, 1980; Warshaw, 1988), opposed to marital rape exemption (Russel, 1982; West, 1990), uncovered the intersection of rape with racism (Wriggins, 1983; Harris, 1990), exposed rape culture (Sanday, 2004) and denounced victim blaming attitudes in judicial inquiries and court audiences (Estrich, 1987; Kennedy, 1993; Koss, 2000; Temkin, 2000; Jordan, 2004; Temkin and Krahé, 2008; Randall, 2010; Hohl and Stanko, 2015). All these analytical dimensions revealed a biased judicial system against women.

As some scholars point out, to research the judicial narratives concerning rape requires the awareness that sexual violence is discursively produced and reproduced by the legal system (Marcus, 1992; Smart 1995; Ehrlich, 2001; Quilter, 2011; Ryan, 2011). Criminal law defines what is unbearable to a certain society and therefore justifies lawful interference; but law has a double dimension of words and actions, so judicial practices (law in action) and social interactions translate, interpret and consolidate the meaning and senses to the words enacted in the Criminal Code. Several academics emphasize that despite law's transformative potential to change gendered structural hierarchies, the effectiveness of its contribution is often compromised by justice procedures and practices (Figueiredo, 1998; Duarte, 2013). Considering sex crimes, some authors expose how legal system can enact and refresh the dominance ideology (Mackinnon, 1991; Coates et al., 1994; Kelly and Regan, 2001, 2003; Jordan, 2004; Kelly et al., 2005; Lovett and Kelly, 2009; McMillan and White, 2015). In the Portuguese context, the one presented in this study, several authors unveil the gender bias in the courtrooms that emerge in processes related to crimes against women (Beleza, 1990; Ferreira, 2003; Martinho, 2011; Sottomayor, 2011; Duarte, 2013).

Normative ideologies of gender and sexuality are produced, reified and crystalized by linguistic codes and social practices. Sociolinguistic studies have put a spotlight on the connections between power and ideology underpinning discourses to the maintenance of gender hierarchies in social relations (Griffith, 1988; Henley and Kramarae, 1991; Cameron, 1992, 1998; Freed, 1992; Eckert and Mcconnell-Ginet, 2003). Critical discourse analysis (CDA) scholars state that gendered power relations are (re)produced, negotiated and, sometimes, confronted in daily discursive interactions (Fairclough, 1989; Gavey, 1989; Lazar, 2007). Lazar (2007) adds that feminist CDA aims to uncover the "ways in which frequently taken-for-granted assumptions and hegemonic power relations are discursively produced, sustained, negotiated, and challenged in different contexts and communities".

This study aims to apprehend the representations, meanings, senses and images of the judicial actors concerning rape, rape victims, offenders, violence, consent and other categories related to sexual crimes. To this end, I have interviewed 18 magistrates (judges and prosecutors) and two lawyers. This article is divided in four sections; the first describes the methodology used; the second concerns the representations and expectations of the magistrates relating the behaviour of rape victims before, during and after the traumatic experience. The third section analyses the connection between the legal request of physical resistance from victims and the offenders' claims of innocence. The last section discusses the role of the courts in the process of reorganizing, validating, translating and reconfigure victims' experiences.

I argue that the emotional performance displayed during audiences is a critical factor to the construction of victim's credibility. The emotional expression of the victim, who is expected to enact the trauma, articulates with the stereotyped imagery of what an offender looks like and behaves. If the accused fits the stereotype of the real rapist (Temkin and Krahé, 2008; Randall, 2010; Edwards et al., 2011), rape allegations will be more believable. Therefore, the victim's response during the attack will be less scrutinized and the demand for physical opposition from the victim will not be so relevant as it is when the accused is a highly functionally and socially successful man (Ventura, 2015). Offenders who do not fit the real rapist stereotype may be more 
successful while claiming innocence, especially when they base their blamelessness either on the victim's consent to sexual intercourse or on their misunderstanding to interpret victim's refusal/rejection (Gotell, 2009; West, 2010; Cowan, 2007).

Finally, I argue that the request for an act of performative trauma from the victim underpinned by her behaviour of physical resistance may exclude some victims from achieving the condemnation of their aggressor and, therefore, failing to accomplish the judicial confirmation of their victimization (Kelly and Regan, 2003; Kelly et al., 2005; Grubb and Turner, 2012).

\section{Methods}

This article results from a larger investigation which combined document analysis with ethnographic methodology. The document analysis focused on legal sources and doctrinal commentary, which included the Portuguese Criminal Code (1852, 1886, 1982 and its revisions in 1995, 1998 and 2007); different editions of the annotated Criminal $\operatorname{Code}^{1}$ as well as other annotations to the sexual offences legal framework; the reports of the parliament debate on legal reforms of sexual crimes and the proceeding books of the work of the different Commissions for the revision of the Criminal Code. The field research aimed to observe the law in action, apprehending the patterns of interactions in the courtroom and to capture the representations of judges, prosecutors and lawyers concerning rape crime and its myths (Burt, 1980).

After contacting 12 courts (eight Criminal Courts and four Courts of Appeal) ${ }^{2}$ (of which five responded and agreed to participate in the research), I began the fieldwork in June of 2012 and ended in December of 2013. The ethnography of the law in action was accomplished with the cooperation of some judges and prosecutors who, first accepted to give me interviews and afterwards, allowed me to observe rape trials. Although trial audiences are open to the public, the Criminal Procedure rules determine that the audience should be excluded during sexual crimes and human trafficking trials (Article No. 87). I observed four rape trials, with 13 audiences overall ${ }^{3}$. During the fieldwork, I interviewed ten judges, eight prosecutors and two lawyers who had professional experience in rape trials (six interviewees worked in higher courts and 12 interviewees were males) ${ }^{4}$.

The interviews followed a script with semi-guided questions, divided by four sections. The first one was about the interviewee's opinion about the law and its adequacy to judicial practices; the second related to the characters of a sex crime criminal process and their performance during trial and the construction of the judicial truth. The third regarded coercion measures and criminal punishment and, finally, the last one referred to the possible security measures for offenders who served the sentence (list of sex offenders, DNA collection), as well as some for the victims (possibility of warning victim when offender is released). Usually,

interviews could take one to one hour and half, but the contact with these actors was extended to the judicial audiences, a time during which I always visited the magistrates work rooms.

Despite the breadth of the material under analysis, this article focuses mainly on the social representations of judicial actors and includes few information on documentary sources.

Interviewees' quotations are differently identified per their professional status, whether if they are judges or prosecutors (identified, respectively, by a J or a P and the number of the interview).

Western Legal systems can be classified into two categories: adversarial and inquisitorial. The outcome of the first one is the result of the efforts and resources of two opposing parties (prosecutor vs defendant) arbitrated by the judge of the process. Differently, in the inquisitorial system the judge is the protagonist of the trial; he/she directly inquires deponents (victims, defendants and other witnesses) and plays an active role during the investigation as well. The differences between the two systems are also visible during courtroom audiences, for example, in the places occupied by the parties. In the Portuguese inquisitorial courts, the magistrates (prosecutors and judges) sit in the same tribune, which is placed on a superior level than the one of the lawyers. Judges and prosecutors' vestments are similar but differ from the ones used by attorneys. While lawyers enter the courtroom through the public door, judges and prosecutors enter from a private entrance located near their tribune. Attorneys, police officers, judicial staff, defendants and public must stand when they enter the courtroom. Subtle and symbolic signs of hierarchies within courtroom may not be evident to a nonprofessional but can be perceived by ethnographic observation.

Adversarial legal system has been specially criticized for being responsible for secondary victimization (Temkin, 2000) and for failing punishing offenders (Lees, 1996, 1997; Ellison, 1997). Still, attrition rates show that the inquisitorial system fails victims too (Lovett and Kelly, 2009; Santos et al., 2009). As stated in a comparative research on rape attrition rates conducted by Liz Kelly, Portugal was one of the countries with a higher attrition rate. Only 11 in every 100 complaints reached court; eight were condemned (Santos et al., 2009).

In Portugal, rape accusations are tried by three judges and, under certain circumstances, it is possible to appeal to higher courts, which will evaluate the case based on the audiotapes recordings of the audiences. Unless the victim is underage rape is not a public crime, thus a formal denounce is mandatory. Rape victims play the role of a testifier during the process and are not represented by an attorney. Nevertheless, Criminal Procedure rules provide victims the possibility of charging the aggressor and, if so, collecting evidence and demanding other procedures along with prosecution. In those cases, victims must pay court fees and hire an attorney. Portuguese State supplies funding for those who prove they have insufficient income, but these cannot choose the lawyer who is going to represent them, since he/she is randomly assigned.

In recent years, criminal procedure rules have changed in order to mitigate secondary victimization, providing a range of possibilities to protect victims; from measures like avoiding testifying in offender's presence (either by removing the defendant from the courtroom while victims testify or by previous recording victim's statement), to prohibiting public audience, and banning media disclosure of victim's name. However, except for the last one, these procedures are not compulsory and depend on judges' evaluation, who may refuse the request(s).

The protection given to women as victims of gender related crimes is conditioned by magistrates' individual frame of references, as well by internalized routines and limitations of the judicial apparatus. ${ }^{5}$

Emotional performance and the real victims. Authors like Smart (1989) argue that law is often far from neutrality, rationality and objectivity; quite the opposite, frequently, exhibits subjectivity and incoherence. The partiality, unintelligibility and disconnectedness that Smart observes are related to the human-condition, and consequently uncertainty, of law. In the Portuguese case, juridical order's instability is intentionally reinforced by the profusion of undetermined legal concepts. Criminal Code lacks the definition of terms like violence, serious threat, inexperience, copulation, relevant sexual act, contact of sexual nature ${ }^{6}$ and their legal use is unsteady under wide discretionary judicial decisions. Furthermore, Portuguese Criminal Code's Introduction $(\$ 14)$ states that "magistrates do not have to stick solely to legal rules". In the same paragraph, there is an appeal to judges' creativity highlighting that they can find the appropriate solution of each case "through the best hermeneutics". ${ }^{\text {? }}$

Legal rules are defined by elites who intend to impose their worldview to others: furthermore, legal definitions and meanings are not universally fixed. Legal norms are interpreted by individuals with moral frameworks and idiosyncratic evaluations. As a judge interviewee points out, even daily constraints may affect the judgment of a legal professional:

I know that saying it like this may sound a bit scary, especially for those who, one day, might be under a criminal prosecution and think: "My God, the guy may have enjoyed his lunch and evaluate the evidence one way or he might have barely slept, be grumpy, and appreciate the evidence other way. And it's true, I won't tell you otherwise". (J17)

These daily tribulations are not under court's discretion, which allows judges to freely assess the evidence. This power is restricted to certain rules like the principle of legality and the rules of experience ${ }^{8}$. Several feminists have argued that this referenced experience is androcentric in its character and therefore excludes women's daily experiences (Mackinnon, 1989; Bem, 1993).

Despite the arbitrariness disclosure in the previous judge's quote, most of the interviewees believed that subjectivity can be surmounted by professional experience over the years. Formal education provides magistrates with tools to evaluate complex technical criminal procedures but lack knowledge concerning psychology and psychopathologies, victimology or gender issues. Thus, the interviewees' difficulties in the identification of the mechanisms used to evaluate witnesses reveal that their decisions are based in non-formal and non-technical tools. Mostly, it sounds as if it was the result of inner wisdom achieved by their professional practice:

Judging is something that cannot be taught. Evidence appraisal can't be taught in university classes, or even during training. It is something that is learned over time. Maybe that is why, in the beginning of the career, we start in smaller courts and over time, as we grow in experience, we will have cases increasingly complex. Moreover, every trial is unique. (J17)

The instability and complexity of the process of judging leads us to a nuclear question: how do judges decide who is credible, and more specifically, how does a real rape victim looks like and behaves (Temkin and Krahé, 2008)? Interviewees' responses uncover their belief of their inner ability to distinguish people who lie from those who do not:

We can tell by the way people express themselves, the way they sit down or move while the others are testifying or even by the way they move their hands (J 8).

We can feel, we feel by the way people express themselves (J1)

This certainty intersects with expected stereotyped gender roles and the imagery related to the real victim myth (Burt, 1980; Du Mont et al., 2003; Bohner et al. 
2009). Judicial actors seem to overestimate victims' emotional manifestation and to look for evidence of their distress, requiring what may be called the trauma show. The absence of poignant and suffering appearance-either by words or body language - can baffle and may even lead to the discredit of the witness. According to rape myths (Burt, 1980), a real victim cries or even expresses runaway emotions while recalling the traumatic experience.

Legal narratives often justify the veracity of victim's testimony based on her ability to express certain feelings in the courtroom, like shame (by blushing), fear, disturbance and pain (hand movements, crying, stammering). Victim's emotional expression is not considered evidence of the crime but has been a legal demand until the 18th century. Medieval heritage emerges in interviewees' representations about the expected attitude of real victims ${ }^{9}$. Stereotyping rape victims' behaviour may distrust those whose deposition performance fails in fitting those patterns. Moreover, as Sharon Marcus argues, rape scripts imprint femininity and the raped woman category reinforces feminine features (Smart, 1989; Marcus, 1992) like those listed above.

Courts of appeal do not see witnesses or offenders since the decision-making process focus on the discursive material gathered by the court of law, therefore, victims' emotional expression is mediated, which can affect magistrates' judgment:

Here, at the court of appeal, we see no eyes, no hands, or other body language expression; which is something so important to try to figure out if someone is uncomfortable with what is being said. But that is something only the judge of the court of law has seen. (J11)

Despite women categorization emerging from judicial discourses, an interviewee disagrees with the idea of the real victim myth: "there is no category of a real victim" (J7). Instead, he adds, "there are credible stories". And what is a real rape story? As stated by the magistrate, an accusation that does not raise doubts of veracity is like this one:

There are circumstances that make an accusation immediately reliable. If a woman is raped in the street, by a smelly beggar, who threatens her with a knife pointed at her throat, drags her into a cane field where he has sex with her, who then runs away, naked, and is immediately helped by passers-by ... this victim is trustworthy because all the circumstances point to her being raped. (J7)

The more an accusation fulfils the imagery theorized by Martha Burt as rape myths (1980) the more credible it will be. The plausible script of a rape allegation emerging from the interviewees' representations refers to the time between the offence and the disclosure of the attack (immediately), the crime scene (isolated, with no witnesses: a cane field), the victim's resistance and marks of violence (wounds) or the use of weapons (knife). Furthermore, an unknown and asocial (beggar, smelly) attacker seals victim's innocence, because, as the same interviewee observes:

A complaint from a person against an unknown aggressor, with whom she has no relationship, has a presumption of veracity. It is something that no one does easily. There is no reason for a woman to accuse a man she does not know; to whom she is not related to or even has ever seen, of having raped her. (J7)

Allegations against known attackers might be received with scepticism (Kelly et al., 2005; Lovett and Kelly, 2009). The myth that women lie and that rape is "an accusation easily to be made and hard to be proved" (Hale as cited in Bourke, 2007) is deeply rooted among judiciary and other professionals who contact with victims (Lovett and Kelly, 2009). Interviewees' imagery about false allegations connects to the idea that women instrumentally use rape complains to get revenge from expartners or on account of regretting consensual intercourse:

Domestic violence is already bad, but accompanied by acts of sexual violence is worse. There are also many women who use this accusation to get a quicker solution for their lives. Not everything that comes to court is true. (J1)

Dates that end in an unhappy way as well as girls who do not conform with the end of the relationship can make such things up because they want to damage the other's life or reputation. (J4)

Accusations within a divorce context emerge as particularly suspicious:

I would say that in those situations judges must pay more attention, I mean, we must wonder 'why she only complained after the divorce? The mother accusing the father of abusing their child with no witnesses? Why only now the child is blaming the father of touching her breast during the bath? This has to be carefully analysed because it arises in a context that raises doubt. (J8)

\section{Consent and physical resistance}

There is nothing in Portuguese law that demands rape victims to bodily resist to a violent physical attack. And yet it is something they cannot renounce to or they risk incredulity from judicial actors, who seem to postulate physical resistance as a requirement to prove sexual aggression. Unless they are under 14, unconscious, or affected by an "intellectual, mental, or physical condition impairment", or in any other way, "unable to resist" (for example, by intoxication or faintness), rape victims are expected to display some kind of resistance "other than words" (Dias 1999, 2012). ${ }^{10}$

The patterns of victim's resistance are not uniform or stable among Portuguese jurisprudence and doctrine. On the contrary, judicial discourses about victim's performance, while repelling an attack, goes from the "utmost resistance" standard to the "lightly or even no physical resistance" one. These opposing narratives coexist in time and space (geographical distinct courts), producing and imposing different and unequal levels of justice, both for defendants and victims. In addition, these dissimilar configurations related to the real victim's behaviour can be found both in ancient and contemporary courts' decisions.

An infamous verdict from the Court of Appeal of Oporto, in 2011, illustrates the most demanding jurisprudence view concerning victim's resistance, and provoked a strong reaction from public opinion and amid judicial actors. The judges acquitted a previously condemned psychiatrist accused of raping his depressed and 8 -month pregnant patient. ${ }^{11}$ The court based the decision on the absence of convincing opposition of the victim and therefore on the therapist's inability to perceive her refusal to have sex with him. The court ruled that regardless her possible rejection or lack of will to engage in sexual intercourse, Portuguese law required the use of physical force and, consequently, the maximum opposition from the victim, irrespective of her consent or dissension. ${ }^{12}$

The idea that sexual contacts are, or may be, preceded by certain violence or urging is also present in interviewees' discourses:

How many times we know and see that sexual encounter between two individuals is the result of one urging the other. (...) The dialogue, the game, the seduction...all of this is interesting but, at some point, due to the unavailability of one of the parts, the other insists and ... insists to ... and then there is the use of force-a physical force-and one obtains, or attempts to obtain, the sexual contact. (P9).

Sexual negotiation emerges as a multifaceted and multidimensional process in which the boundaries between consent and violence are difficult to define (Gavey, 1999, 2005). Although this prosecutor ensures that "to make the victim yield already translates the practice of a crime", law in action reveals the interstices of this interpretation. One of the issues to be addressed is the magistrates' difficulty in understanding behaviours that looks incomprehensible to common sense. The complexity of fear, which induces responses such as tonic immobility is poorly understood. The absence of physical or verbal opposition is perceived as "passivity" or even appreciation (no is yes) and is usually taken as an indicator of a compliant victim.

The story of a "precociously flirty" adolescent (as described by the interviewee), who accuses an adult of raping her, reveals that judgments about victims' sex lives, or lifestyle, operate as extralegal elements that shape the process of evidence appraisal and final verdict. This is the story of

A fourteen-year girl that played a prank on a man of 29. They used to get together and lay down together, she would let him grope her and groped him back, but each time they got to the moment of intercourse, she always said no. And this was always the same: they were together and he wore shorts, they went to bed, got involved and performed foreplay, but 
penetration never happened. That's why I say she played a prank on him (J7).

The description and considerations from the interviewee about the case focus mainly on the girl's characteristics (her body resembled that of an adult, she behaved in a non-normative way). But nothing emerges about the aggressor (marital status, profession, emotional, romantic or sexual history, or other elements). We are only informed that he is an adult, 29 years old, who is dating a 14 year old girl. The adolescent is seen as "almost a victim" but not a real victim since she allowed and actively involved herself in a set of actions that could lead to copulation, which she always refused. The collective of judges will conclude that the situation reported by the minor does not constitute a crime and acquit the aggressor:

Our conviction was that in that day he thought something like 'it must be today! I've had enough of never ending foreplay that never result in sex, and so today must be the day'. But then she did not comply, because it was not what she wished for. She just wanted to play-although she was no longer a virgin and already had sex with her boyfriend-so she says no, starts crying and declares "I don't want to'. And after this, he gets violent with her, pushing her to the bed and saying, 'you are not going anywhere! It has to be today!" (J7)

The principles outlined by the respondent to explain the acquittal of the offender suggest that the victim is assessed by her previous sexual behaviour and the lack of physical opposition from her, which seems inexplicable to the magistrate:

The truth is that it, after this act of resistance ... she rose... she had the door... but he did not assault her, didn't shout at her, didn't do anything else to her. He told her to undress, which she did and then had sex with him. Not very willingly, I believe, because after that she got out of there and denounced him to the police. He was acquitted, we absolved this man. (J7)

The possibility that she was terrified in the view of his unprecedented aggressive and threatened behaviour, or that she might find that any other act of resistance from her would be useless, or could get him more irritated, is not credible to the judge:

(...) She says 'I do not want', and then he grabs her shoulders and pushes her to the bed but eventually she submits to his demands. She let herself go (...) she could have run away, but she didn't. She undressed and agreed to have sex (J7).

The demands for victim's physical opposition are very ancient. For centuries, victims were encouraged to react strongly with unequivocal opposition and continued resistance (Brownmiller, 1975; Beleza, 1990; Bourke, 2007). However, what is considered to be reliable resistance depends on the characteristics of the involved. In this case, what is at stake transcends the assessment of the intensity of violence used during the assault, or the victim's resistance and her apparent "withdrawal of opposition". These dimensions intersect with victim's and aggressor's characteristics. Thus, the connection between the victim and the offender (prior knowledge but no official relationship and non-penetrative sexual contact), along with her lifestyle (not a virgin, "flirty adolescent", dating an adult while having a boyfriend) are major aspects for the acquittal verdict.

Despite the recognition that the teenager did not want to copulate with the adult, the decision-maker couldn't find any causal link between the "withdrawal" of her opposition and the aggressive behaviour of the perpetrator. The respondent considers that the minor's obedience to the adult turns the situation cloudy, leading to what he called a "borderline case":

Unless she continued to resist he could not tell whether she was consenting or not, because from the moment she silences herself, undresses and lays down with him, even if she did not want to (...) we considered that, in that context, he had no way of knowing that it was against her will. (J7) ${ }^{13}$

The respondent ensures that "after" [the violence] she just "accepted" having sex. This observation assesses the apparent victim's acquiescence as if it was isolated from the previous events.

The victim emerges as an almost adult and calculating character (reporting to the police to upset the abuser), that instrumentally uses the possibility to complaint. The attacker appears as a victim of a seductive and frivolous Lolita who totally disregards his sexual needs. And, despite the age difference between the characters only the minor is required to manifest the aptitude to continually resist and not be intimidated. Simultaneously, it is assumed that an adult does not have the ability to ask and to relate the attitude of the girl with the violence previously inflicted against her.

The argument to support the idea that the aggressor could not clearly perceive if the minor was dissenting is similar to the one used to acquit the psychiatrist who raped his depressed and pregnant patient. Both decisions are justified on the ground of absence of reliable opposition from the victims, and consequently, in the attacker's impossibility to realize victim's dissent.

Consent, violence and resistance arise inexorably linked. Although most of the respondents refuse the idea that the law disregards victims' consent, the evaluation of their dissension depends on their opposition:

In some way, the very concept of violence already includes the concept of opposition or dissension, because if some violent act does not face dissension there is no rape. Sometimes, we only can characterize the act as violent because there was opposition from the victim-presumed or displayed. (J7)

However, as shown in the previous episode reported by the same respondent, equal reactions from dissimilar victims can be differently interpreted and valued by magistrates. As we have seen, victim's opposition must meet certain requirements, namely continuity:

I don't think judge's evaluation lies in the victim's opposition but in the degree of violence that the attacker uses. Nonetheless victim's consent is not indifferent to evaluate whether the act was violent or not. If we are talking about a threat with a knife, a pistol, a physical assault ... someone who beats the victim and who has superior physical strength than hers, then the victim's resistance is indifferent. In these cases, I have no doubt describing the act as violent whether there was or wasn't opposition from the victim, but if eventually the victim says: 'okay, I accept to have sex with you ...-i.e. although there was violence-there is no rape. Because to be a rape it is necessary that the act is not consented to by the victim. Any consented sexual act, even though involving violence, is not rape. It is an aggression, a bodily injury, though. (J7).

The connection between consent, violence and opposition is not easily defined; it results plastic and mouldable depending on the characters involved. The situations in which it is assumed that victims do not react are those of exceptional violence (beatings, use of weapons) and other deterrents come as easily to be overtaken by victims. 


\section{Courts and the power to conclude}

Several studies point to the secondary role of victims during the criminal process. The personal accounts gathered by researchers and rape centre crisis disclose that prosecutors are seen as distant by victims and often not responsive to their needs (Holmstron and Burgess, 1991; Kelly and Regan, 2003; Kelly et al., 2005; Lovett and Kelly, 2009). Despite the victim might be one of the most (or the most) important of all witnesses, during the trial her role is merely instrumental, and her interests are not considered.

The primary goal of law is to restore the normative balance deteriorated by the criminal action. It is the protection of legality that is the main subject of a trial, not the reposition of victim's legal interest; therefore, the process is essentially between the offender and the State. This logic is emphasized by legal system's focus on the offender:

The ultima ratio is to deprive someone from their freedom, even if he/she have made an unspeakable act as rape. Is to believe that everyone deserves a consideration. And specially when the law has an increasingly desire to please the accused -much more than to please victims. (P11)

From a procedural point of view, our law is very uneven, very focused on defendant's rights and, in a certain way, doesn't care about the victims, who are used as evidence. For the law, the victim is not that important. (P10).

In addition, rape victims speak about their emotional state, which is juridical irrelevant since is not regarded an objective evidence of the crime. In the process of pursuing factualism, feelings are not viewed as facts, and therefore rarely appear in judicial narratives:

Feelings are not part of legal system. In courts or judicial decisions, they never talk about the victim's feelings, no one ever knows how the victim felt. (...). It is as if the person was an object: there she is, still, while they say: they made her this and for that the penalty is $\mathrm{X}$ years. I think this happens because per criminal law feelings are not facts. Nevertheless, this is contradictory because there are many legal rules-for instance in family law-that refer to the affective relationship, or in legal agreements that explicit the intent to harm others and the possibility to withdraw a contract signed by a depressed person. (J16)

Consequently, witnesses' discourses need constant readjustment. Victims may recall what they felt rather than the details of what happened. Moreover, not all the particulars interest to judges and prosecutors. They insist on the quantitative dimension of the enquiry: "How old were you when it all started? And on another occasion, in the car, how old were you?". It is persistently asked how often or how frequently the facts occurred ["could have been once a week? Once a month? How many times?"], as well as the number of people involved, dates and exact locations, a clear chronology and a straightforward narrative, without any accessory elements. But few witnesses are able to testify with that judicial competence, especially if they have no legal advice.

While chasing the factual truth, courts make the accountancy of pain and suffering, by turning those feelings into something countable and tangible, assessing the extent of damage, summing up any material loss (for example, torn garments, hospital and other therapeutic consultations invoices, number of days of work or school absenteeism). Victims of theft may react without strangeness to questions about the value of the property that was subtracted from them. However, victims of sexual crimes can react with perplexity as illustrated in this excerpt:

Judge: so, they took your pants?

Victim: Yes.

Judge: and how much did the pants cost?

Victim: How much did the pants cost? I don't know.

Judge: But can you have an idea? What kind of pants they took?

Victim: It was a pair of normal jeans.

Judge: Yes, but there are jeans that cost $20 €$ and others that cost $100 €$.

Were they from an expensive brand?

Victim: no, they were a normal pair of jeans, maybe $20 €$.

(Daily fragment field, March 2013)

The importance given to the facts accountancy by judicial actors is achieved through a selection of deponents' discourses, which are filtered to choose what is considered legally relevant. This editing process often results in the loss of multidimensional aspects, particularly those related to the victim's feelings at the time of and after the facts.

Judicial discourses may be like a foreign language to nonexperts. Illustrative of that oddness reaction is the following quotations of a witness of rape during trial audience. While trying to describe the facts, the deponent, who had been beaten and witnessed his girlfriend being raped, concludes: "and then she was raped"; but the judge elucidates him he must tell the court "everything". At that moment, he admits: "I do not know how to say it". His revelation exemplifies the difficulty in reporting the facts of a traumatic experience, but also the ignorance regarding legal language (Branco, 2014). However, his disclosure is not included in the written sentence nor is his other confession while describing the events: "and then I saw what no one expects to see in life".

The judicial narrative of facts undergoes a process of purification and transformation. The discourses are reduced to what is considered to be legally valuable: visible body injuries or, if invisible, confirmable by forensic experts, verbal abuse (witnessed by others), duration of the aggression and its intensity. The judicial construction of the crime lies in the inventory of tangible damages.

The judicial preference for experts' reports and statements, which are regarded as more reliable than those of non-experts (Fairclough, 1995; Smart, 1995; Machado, 2008; Rees, 2010), result from the judicial practices and social actor's representations as well as from the procedural rules. These interdict judges of freely appreciating evidence given by specialists. In contrast to the confidence in forensic institutions, some respondent's discourses foresee lay's devaluation:

When someone press charges against other for broking his arm, the arm will be no longer broken by the time of the court audience; but there is a medical report that corresponds to a witness. If it is of an expert ... great! It is unquestionable! But if it is a witness that says: 'I saw him with a broken arm'-ok, but what is a broken arm? A non-specialist witness will tell us what he/she saw, and may even remark, 'yes, I saw the wounds in his broken arm'-but he can't tell us what caused the wounds or if the wounds were really those of a broken arm! (P9).

The observation of the interviewee reveals the non-recognition of external elements to the legal universe, which are looked upon with suspicion. In addition, the requirement for "details" exposes the hierarchy in the valuation of testimonies. It is not expected 
that a non-expert witness will make a conclusion, but only to describe what he/she saw or heard. The power to conclude strictly belongs to experts, particularly judicial ones. Illustrative of this authority is the explanation of an interviewee about the statement of the previous quoted victim:

When he said 'and then she was raped', for him the story had ended. But that cannot be. We need to know the details. 'Was raped' is a conclusion. I have to know what happened to conclude that it was rape. (J14)

Prosecutors conclude that the acts described are rape and press charges against the offender; judges conclude that the defendant should or should not be convicted. The ability to conclude is also the power to name and define experiences. Victims may exit the court without seeing their victimization recognized as a crime, or being renamed into something in which they shall not recognize their traumatic experience (for example, sexual harassment, sexual coercion, sexual abuse of person incapable of resistance or others).

\section{Conclusions}

The information obtained show that Portuguese judiciary is given discretionary powers to interpret the law, therefore constituting a group of strong regulation of social and sexual roles, with the authority to classify, define and name the experiences of the involved in criminal processes. In addition, judicial interpretation's uncertainty results in the legal exclusion of certain forms of unwanted sexual interaction.

In the discursive reconstitution of facts, victim's experience is renamed, classified and standardized. The court tells the story of the penetrating phallus and describes in detail the sectioned and penetrated body. Victims are reduced to the parts touched by the other; primarily, the vagina, vulva, clitoris, but also breasts, anus, buttocks, thighs, mouth and tongue. Thus, victims are objectified or sexualized, as Carol Smart observes (1995). They go back to the sexual object condition to which the abuser reduced them at the time of victimization. At the beginning of the trial, a magistrate publicly reads the indictment. The description of the rape is then transformed into a pornified narration (Coates et al., 1994), sometimes romanticized and eroticized (hands caressing breasts or buttocks, mouths kissing other mouths, bodies embracing each other). Carol Smart argues that a rape trial can be "described as a specific form of sexualizing a woman's body (a body already sexualized by phallocentric cultural codes), since it is her body and her reactions that are the subject of evidence", therefore, during the trial, the body "becomes literally saturated with sex" (Smart, 1995).

Portuguese legal discourses about raped women reinforce the ancient and shallow Madonna-whore binary. Female victims emerge both as sexually well-behaved and modest, who strongly oppose their attacker or, on the opposite, devoid of decency, weak-minded, untrustful and ambivalent. Accusations against unknown attackers are considered the most credible followed by those of victims who display forensic evidence of physical struggle and emotively reveal shame and pain while giving evidence at the courtroom. Emotional performance arises as a fundamental element for the assessment of victim's reliability in courts of law, but loses impact in higher courts, where the direct observation of deponents is not possible.

The judiciary framework to evaluate both offender and victim follows a diffuse and complex appraisal method that articulates the violence imposed with a victim's opposition performance. A defendant's criminal background and social status, as well as plaintiff's sexual history, intersect with the assessment of victim's resistance.
Legally, a recognition of women's autonomy to refuse sexual advances is subjected to discretionary magistrates' readings of offenders' conduct and intentions. Allegations of misinterpreting sexual rejection by defendants are tolerated by jurisprudence and doctrine, and so raping women, whose expression of sexual refusal is considered dubious or ambiguous, might not be criminal punished.

The judicial exclusion of victims' perspectives may relate to the airtight, distant and seemingly factual style of judicial discourses, which are believed to be neutral and objective. However, neither victims' nor aggressors' statements define or express their experiences in the way legal discourses do. Thus, the judicial narratives of rape are reconfigurations of the outcome of the testimonies of victims, aggressors and other deponents altogether with the ones of the experts. Victims are subjected to forensic examinations that scan the body (and mind) and their behaviour is evaluated to confirm their reliability and to build a story that will be performed during the audience.

\section{Notes}

1 The first Portuguese Criminal Code was enacted in 1852, Data included one annotated Criminal Code of 1852, seven for the Criminal Code of $1886(1917,1938,1946$, 1950, 1960, 1969, 1979), three for the Criminal Code of $1982(1986,1988,1992)$ and three for the posterior legal revisions of 1995, 1998 and 2007 (1999, 2000, 2012). In addition, data comprehended smaller annotations from jurists about sexual crime section in the Criminal Code (1924, 1926, 1933, 1982, 1994, 1995, 1996, 2008, 2009, 2011).

2 For confidentiality reasons the location of these courts cannot be revealed.

3 It is note to say that the researchers' access to Portuguese courtrooms is not easy (Rodrigues, 2005) and that might explain the scarce number of investigations with ethnographic methods.

4 According to the Direção-Geral da Política de Justiça (General-Directorate for the Policy of Justice) (DGPJ), the number of female judges has increased and during 2013 it had reached $58 \%$ of the judges in courts. The gender asymmetry is particularly accentuated among the prosecutors (62.3\% are female). However, in higher courts, the number of women is little more than half of their colleagues. In Supreme Court, there are eleven times more male judges than females. In conclusion, the feminization of the profession occurs mostly in less advanced [and less privileged] stadiums of the career. The presence of women is clearly reduced in the higher courts, particularly among judges. In 2013, female lawyers represented 54\% of the attorneys registered in the Portuguese Bar Association; one percent more than in the previous year.

5 Some of those limitations might be of architectonic type: Portuguese courts are not prepared to assure that defendant and victim do not cross paths. Unless the defendant is preventively imprisoned, victim and aggressor will enter the court through the same door, will wait to be called in the same waiting room, and the victim waits in the same witness's room as all other deponents, who might be, for example, the defendant's family and friends.

6 For centuries, Portuguese jurisprudence and doctrine have discussed the senses and meanings of (female) virginity, decency, modesty, seduction, abuse of inexperience, serious promises to wed, resistance, sexual act analogous to copulation, among others. Legal concept's indeterminacy allowed (and still does) some courts of law to consider the copulation to be the penile penetration of the vagina until ejaculation (adopting the medical concept), while other courts of law exempted the ejaculation. Some courts of law considered the hymen to be evidence of virginity but others regarded virginity as a general state of innocence and inexperience that could dispense the hymen's physical integrity.

7 Decision makers' limits are bordered by the Constitutional rules and legality, which means they cannot use their "creativity" to punish any licit action.

8 In Portuguese Code of Criminal Procedure Article No. 127 (free evidence appraisal) states: "Unless the law provides otherwise, the evidence is assessed according to the rules of the experience and the free conviction of the competent authority".

9 Medieval Ordinances (in force until the enactment of the first Portuguese Criminal Code, in 1852) required victim's emotional expression translated into screaming: "(...) shouting out and screaming: see what he has done to me (....) and naming him. And she must weep and cry, complaining to the first and the second and third, and then all the others with whom she crosses her path with, and must go to court and not entering another house. And if any of these clauses is missing the complaint is not valid." (Book I, Title vi, $\$ 29$ The forced woman and how to prove she was forced).

10 In Portuguese Criminal Code, sex crimes are found in the "Crimes against sexual freedom and self-determination" chapter and have two sections: one for "crimes against sexual freedom", which includes rape and crimes against victims of all ages; and "crimes against sexual self-determination" exclusively for minors. The latter comprehends acts committed with no violence or even with victim's consent, which is 
considered legally irrelevant, since victims are under 14 . Article No. 164 - rape: "1Who, through violence, serious threat, or after, to this end, made the person unconscious or unable to resist, compels another person: a) to suffer or to practice with him/her or with others: copulation, anal or oral coitus; or b) to undergo vaginal or anal introduction of objects or body parts; is punished with imprisonment of 3-10 years. 2-Who, by any other means not included in the preceding paragraph, constrains another person: a) to suffer or to practice with him/her or with others, copulation, anal or oral coitus; or b) undergo vaginal or anal introduction of objects or body parts; is punished with imprisonment from 1 to 6 years." The second paragraph is the result of legal changes in 2015, after the country ratified the Istanbul Convention. The aim was to punish any sexual acts made without victim's consent. Nevertheless, Portuguese legislators refused to enact a rape law based on victim's dissent. The previous version (until 2015) of the second paragraph was an essay to punish sexual harassment. Instead of "by any other means", the rule punished the abuse of "authority resulting from a family relationship, guardianship or trusteeship, or hierarchical dependence, economic or employment, or taking advantage of the fear caused by the agent". Punishment was "up to three years". Besides rape, Portuguese law also incriminates "sexual assault against a person unable to resist" (Article No. 165 ) and "sexual abuse of an interned person", which may include people imprisoned or admitted into health facilities.

11 One of the three judges voted against the decision.

12 The story involves a psychiatrist with good professional reputation and his 34 weeks' pregnant patient with a diagnosis of depression. After acquitting the accused, the court alludes to the moral and social disapproval of the acts in trial, ensuring that nothing written in the sentence excludes "the reprehensibility of the defendant's conduct in ethical and even social terms." However, concerning the rape accusation, the court assures there is no room in the Portuguese Criminal Code to punish someone who, "taking advantage of the advanced state of pregnancy which hindered her movements", grabs the victim "turns her back, pushes and bends her over toward the couch, lowers her maternity pants and introduces his erect penis in her vagina until the ejaculation'; and then 'introduces his penis into victim's mouth, grabbing her head", (Judicial sentence of the Court of Appeal of Oporto, 13-04-2011). The case was first trialled in a court of law that found the psychiatrist guilty of rape and condemned him to a suspended prison sentence of 5 years.

13 A principle common to contemporary Western law is that only guilt justifies punishment. Guilt is a multidimensional result that implies criminal thinking (mens rea) and the culpable actions (actus rea). The mens rea (guilty mind) has been used in Anglo-Saxon countries as a strategy of defence for cases of sexual assault. The argument is the mental lapse of aggressors, based on the lack [or misconception] concerning the dissension of the assaulted person. The Portuguese correspondence of mens rea is intent (dolo). It is regulated in the Criminal Code chapter on assumptions of punishment, along with negligence and error. To be punishable, Portuguese law requires that the agent acts be motivated by malice or intent, or that his actions are consequence of negligent behaviour, or even error. Examples of the latter are the mistake concerning victim's age, or relating to the unlawfulness of the conduct. The Criminal Code describes three forms of intent: direct, necessary and possible. In the first one, agent acts with criminal intent and so he is aware of the unlawfulness of his conduct but does it anyway; in the second one, the agent knows that the conduct is likely a wrongful act, but decides to do it anyway. In the third, the agent predicts the result of the conduct as a possible wrongful act, but still do not abstain from the undertaking it. Concerning rape and sexual coercion, aggressor's intent is measured by perpetrator's anticipation of victim's resistance. Several authors have been contributing to the debate of the "guilty mind" issue, for example, Pamela Haag (1999), Sheila Duncan (1995), Lois Pineau (1989), Catherine Mackinnon (1989, 2003, 2016), 92Lucinda Vandervort (1986), Carole Pateman (1980). Suggestions to improve legal clearance of consent in sex crimes have been presented by many feminists as Martha Chamallas (1988) or Stephen J. Schulhofer (1992). Schulhofer advocates the replacement of the concept of consent by "mutuality", supporting the criminalization of "nonviolent interference with sexual autonomy in cases in which a woman's silence or ambivalent conduct does not provide assurance of her desire in sexual intercourse" (quoted in Chamallas 1999: 220-1)

\section{References}

Beauvoir S (1949) Le deuxième sexe. Gallimard: Paris, France.

Beleza T B (1990) Mulheres, direito, crime ou a perplexidade de Cassandra. AAFDL: Lisboa, Portugal.

Beleza T B (1994) O conceito legal de violação. Revista do Ministério Público [separata]; 59 (3): 51-64.

Beleza T B (1995) A regulação jurídica da sexualidade no Código Penal: da laicização dos "bons costumes" à ortodoxia da "liberdade" Estudos comemorativos do $1500^{\circ}$ aniversário do Tribunal da Boa-Hora. Ministério da Justiça: Lisboa, Portugal, pp 169-173.

Beleza T B (1996) Sem sombra de pecado: O repensar dos crimes sexuais na Revisão do Código Penal Jornadas de direito criminal: revisão do Código Penal; vol. I [separata] CEJ-Centro de Estudos Judiciários: Lisboa, Portugal, pp 157-183.

Bem S L (1993) The Lenses of Gender: Transforming the Debate on Sexual Inequality. University Press: Yale, CT.
Bevacqua M (2000) Rape on the Public Agenda: Feminism and the Politics of Sexual Assault. Northeastern University Press: Boston, MA.

Bohner G, Eyssel F, Pina A, Siebler F and Viki T (2009) Rape myth acceptance: Cognitive affective and behavioural effects of beliefs that blame the victim and exonerate the perpetrator In: Horvath M. and Brown J. (eds) Rape: Challenging Contemporary Thinking. Willan: Devon, UK, pp 17-45.

Bourke J (2007) Rape: A History from 1860 to the Present. Virago: London.

Branco S (2014) A compreensão da terminologia legal por adultos. Dissertação de mestrado em Medicina Legal. Instituto de Ciências Biomédicas de Abel Salazar: da Universidade do Porto.

Brownmiller S (1975) Against Our will: Men, Women and Rape. Simon \& Schuster: New York.

Burt M (1980) Cultural myths and supports for rape. Journal of Personality and Social Psychology; 38 (2): 217-230.

Cameron D (1992) Feminism \& Linguist Theory. Palgrave Macmillan: London.

Cameron D (1998) Gender, language and discourse: A review essay. Signs; 23 (4): 945-973.

Chamallas M (1988) Consent, equality and the legal control of sexual conduct. Southern California Law Review; 61 (4): 777-862.

Coates L, Bavelas J B and Gibson J (1994) Anomalous language in sexual assault trial judgments. Discourse \& Society; 5 (2): 189-206.

Cowan S (2007) Choosing freely: Theoretically reframing the concept of consent In: Hunter R and Cowan S (eds) Choice and Consent: Feminist Engagements with Law and Subjectivity. Routledge-Cavendish: New York, pp 91-104.

Dias J F (ed) (1999) Comentário conimbricense do Código Penal; Parte Especial, tomo I: art. $131 .^{\circ}$ a $201 .^{\circ}$ Coimbra Editora: Coimbra, Portugal, pp 340-598.

Dias J F (ed) (2012) Comentário conimbricense do Código Penal; Parte Especial, tomo I: art. ${ }^{\circ} .131 .^{\circ}$ a $201 .^{\circ}$ Coimbra Editora: Coimbra, Portugal, pp 550-900.

Duncan S (1995) Law's Sexual Discipline: visibility, violence and consent. Journal of Law and Society; 22 (3): 326-352.

Du Mont J, Miller K and Myhr T (2003) The role of "real rape" and "real victim" stereotypes in the police reporting practices of sexually assaulted women. Violence Against Women; 9 (4): 466-486.

Duarte M (2013) Para um direito sem margens: representações sobre o direito e a violência contra as mulheres. Tese de doutoramento em Sociologia na área científica do Estado, do Direito e da Administração: Universidade de Coimbra.

Eckert P and Mcconnell-Ginet S (2003) Language and Gender. University Press: Cambridge, UK.

Edwards K, Turchik J, Dardis C, Reynolds N and Gidyez C (2011) Rape myths: History, individual and institutional-level presence, and implications for change. Sex Roles; 65 (11): 761-773.

Ehrlich S (2001) Representing Rape: Language and Sexual Consent. Routledge: New York.

Ellison L E (1997) A comparative study of rape trials in adversarial and inquisitorial criminal justice systems. PhD. Thesis. Faculty of law. University of Leeds.

Estrich S (1987) Real Rape: How the Legal System Victimizes Women who Say no. Harvard University Press: Cambridge, MA.

Faedi B (2009) Rape, blue jeans and judicial developments in Italy. Columbia Journal of European Law; 16 (1): 13-18.

Fairclough N (1989) Language and Power. Longman: London.

Fairclough N (1995) Critical Discourse Analysis: The Critical Study of Language. Longman: Harlow, UK.

Ferreira C (2003) O discurso dos juizes sobre a violação. Dissertação de candidatura ao grau de mestre. Universidade do Minho.

Figueiredo D C (1998) Identities and gender in discourse of rape trials. Fragmentos; 7 (2): 85-104.

Foucault M (1976) Histoire de la sexualité: La volonté de savoir. Gallimard: Paris, France.

Freed A (1992) We understand perfectly: a critique of Tannen's view of cross-sex communication. In: Hall K, Bucholtz M and Moonwomon B (eds). Locating power: Proceedings of the second Berkeley women and language conference. vol. 1, Berkeley Women \& Language Group: Berkeley, pp 144-152.

Fuller P (1995) The social construction of rape in court appeal cases. Feminism \& Psychology; 5 (2): 154-161.

Gavey N (1989) Feminist poststructuralism and discourse analysis: Contributions to feminist psychology. Psychology of Women Quarterly; 13 (4): 459-475.

Gavey N (1999) 'I wasn't raped but...,' Revisiting definitional problems in sexual victimization In: Lamb S (ed) New Versions of Victims: Feminist Struggle with the Concept. New University Press: New York, pp 57-82.

Gavey N (2005) Just sex? The cultural scaffolding of rape; New YorkRoutledge.

Gotell L (2009) Rethinking affirmative consent in Canadian sexual assault law: neoliberal sexual subjects and risky women. Akron Law Review; 41 (4): $865-898$.

Griffin S (1971) Rape: the all-american crime. Ramparts; 10 (3): 26-35.

Griffith M E (1988) Sexism, language and the law. West Virginia Law Review; 91 (125): 125-151. 
Grubb A and Turner E (2012) Attribution of blame in rape cases: a review of the impact of rape myth acceptance, gender role conformity and substance use on victim blaming. Aggression and violent Behavior; 17 (5): 443-452.

Haraway D (1991) A cyborg manifesto: science, technology, and socialist-feminism in the late twentieth century In: Simians, Cyborgs and Women: The Reinvention of Nature. Routledge: New York, pp 149-181.

Haag P (1999) Consent: sexual rights and the transformation of American Liberalism. Cornell University Press: Ithaca.

Harris A (1990) Race and essentialism in Feminist legal theory. Stanford Law Review; 42 (3): 581-616.

Helliwell C (2000) It's only a penis: rape, feminism and difference. Signs; 25 (3): 789-816.

Henderson L (1992) Rape and responsibility. Law \& Philosophy; 11 (1): 128-178.

Henley N and Kramarae C (1991) Gender, power and miscommunication. In Coupland N, Giles H and Wiemann J (eds). Miscommunication' and problematic talk. SAGE: Newbury Park, CA, pp 18-43.

Hohl K and Stanko E (2015) Complaints of rape and the criminal justice system: Fresh evidence on the attrition problem in England and Wales. European Journal of Criminology; 12 (3): 324-341.

Holmstron L and Burgess A W (1991) The Victim of Rape: Institutional Reactions. Wiley: New York.

Jackson M (1984) Sex research and the construction of sexuality: A tool of male supremacy? Women's Studies International Forum; 7 (1): 43-51.

Jordan J (2004) The Word of a Woman? Police, Rape and Belief. Palgrave: London.

Kelly L, Lovett J and Regan L (2005) A Gap or a Chasm? Attrition in Reported Rape Cases. Home Office Research: London.

Kelly L and Regan L (2001) Rape: The Forgotten Issue? A European Research and Networking Project. Child and Woman Abuse Studies Unit: London.

Kelly L and Regan L (2003) Rape: Still a Forgotten Issue?; Briefing document Child and Woman Abuse Studies Unit: London.

Kennedy H (1993) Eve was Framed: Women and British Justice. Vintage Edition: London.

Koss M (2000) Blame, shame, and community: Justice responses to violence against women. American Psychologist; 55 (11): 1332-1343.

Lazar M (2007) Politicizing gender in discourse: feminist critical discourse analysis as political perspective and praxisFeminist Critical Discourse Analysis: Gender, Power and Ideology in Discourse. Palgrave Macmillan: London, pp 1-29.

Lees S (1996) Carnal Knowledge: Rape on Trial. Hamish Hamilton: London.

Lees S (1997) Ruling Passions: Sexual Violence, Reputation and the Law. Open University Press: Buckingman, UK.

Lovett J and Kelly L (eds) (2009) Different systems, similar outcomes? tracking attrition in reported cases across Europe. Child and Women Abuse Studies Unit: London.

Machado H (2008) Biologizing paternity, moralizing maternity: the construction of parenthood in the determination of paternity through the courts in Portugal. Feminist Legal Studies; 16 (2): 215-236.

Mackinnon C (1989) Toward a Feminist Theory of the State. Harvard Press University: Cambridge, MA.

Mackinnon C (1991) Reflections on sex equality under law. The Yale Law Journal; 100 (5): 1281-1328.

Mackinnon C (2003) A sex equality approach to sexual assault. In Annals New York Academy of Science 989 (I Sexually coercive behaviour: understanding and management), pp 265-275.

Mackinnon C (2016) Rape redefined. Harvard Law \& Police Review; 10 (2): 431-477.

Marcus S (1992) Fighting bodies, fighting words: A theory and politics of rape prevention. In Butler J and Scott J (eds). Feminists theorize the political. Routledge: New York, pp 386-403.

Mardorossian C (2002) Toward a new Feminist theory of rape. Signs; 27 (3): $743-775$

Mardorossian C (2014) Framing the Rape Victim: Gender and Agency Reconsidered. Rutgers University Press: New Brunswick, NJ.

Martinho G F (2011) Crimes sexuais contra mulheres adultas: da avaliação forense à decisão judicial. Dissertação de mestrado em Psicologia, especialização em Psicologia da Justiça, Universidade do Minho.

McMillan L and White D (2015) 'Silly girls' and 'nice young lads', vilification and vindication in the perceptions of medico-legal practitioners in rape cases. Feminist Criminology; 10 (3): 279-298.

Pandey S (2014) Women's health and law in India: trends of hope and despair. In Kannabiran K (ed). Women and law: Critical feminist perspectives. Sage: New Delhi, pp 206-238.

Pateman C (1980) Women and consent. Political Theory; 8 (2): 149-168.

Pineau L (1989) Date rape: A feminist analysis. Law \& Philosophy; 8 (2): 217-243.

Potts A (2002) The Science/Fiction of Sex: Feminist Deconstruction and the Vocabularies of Heterosex. Routledge: London.

Quilter J A (2011) Re-framing the rape trial: Insights from critical theory about the limitations of legislative reform. Australian Feminist Law Journal; 35 (1): 23-56.
Randall M (2010) Sexual assault law, credibility, and 'ideal victims': consent, resistance and victim blaming. Canadian Journal of Women and Law; 22 (2): $397-434$.

Rees G (2010) 'It is not for me to say whether consent was given or not': Forensic Medical Examiners' construction of 'neutral reports' in rape cases. Social and Legal Studies; 19 (3): 371-86.

Rodrigues M C (2005) Contributos para a análise da linguagem jurídica e da interacção verbal na sala de audiências. Dissertação de doutoramento em Linguística apresentada à Faculdade de Letras da Universidade de Coimbra, Portugal.

Russel D (1975) The Politics of Rape: The Victim's Perspective. Stein \& Day: New York.

Russel D (1982) Rape in Marriage. Macmillan: New York.

Ryan K (2011) The relationship between rape myths and sexual scripts: the social construction of rape. Sex Roles; 65 (11): 774-782.

Sanday P R (2004) Rape-prone versus rape-free campus cultures. In kimmel M and Plante R (eds). Identities, Behaviours and Society. Oxford University Press: New York, pp 428-437.

Santos J, Rodrigues M, Vieira R, Nikolic D, Kelly L and Lovett J [coord.] (2009) Diferentes sistemas, resultados semelhantes? Identificar o atrito em casos de violação registados em onze países. Delegação do Sul do Instituto Nacional de Medicina Legal.

Schulhofer S (1992) Taking sexual autonomy seriously: rape law and beyond. Law and Philosophy; 11 (2): 35-94.

Smart C (1989) Feminism and the power of law. Routledge: New York.

Smart C (1995) Law's power, the sexed body, Feminist discourse. In Law, Crime and Sexuality: Essays in Feminism. Sage: London, pp 70-86.

Sottomayor C (2011) O conceito legal de violação: um contributo para a doutrina penalista a propósito do acórdão do Tribunal da Relação do Porto, de 13 de Abril de 2011. In Revista do MinistérioPúblico [separata]; 32 (128): 273-318.

Temkin J (2000) Prosecuting and defending rape: Perspectives from the bar. Journal of Law \& Society; 27 (2): 219-230.

Temkin J and Krahé B (2008) Sexual assault and the justice gap: a question of attitude. Hart Publishing: Oxford and Portland, Oregon.

Toit L (2009) A Philosophical Investigation of Rape: The Making and Unmaking of the Feminine Self. Routledge: New York.

Vandervort L (1986) Mistake of law and sexual assault: consent and Mens Rea. Canadian Journal of Women and Law; 2 (2): 233-309.

Ventura I (2015) Um corpo que seja seu: podem as mulheres [não] consentir? Ex aequo; 31 (1): 75-89.

Vigarello G (1998) História da Violação: Séculos XVI-XX. Editorial Estampa: Lisboa, Portugal.

Walby S (1990) Theorizing Patriarchy. Basil Blackwell: Oxford.

Warshaw R (1988) I never called it rape. Harper\&Row: New York.

Watson-Franke M (2002) A world in which women move freely without fear of men: an anthropological perspective on rape. Women's Studies International Forum; 25 (6): 599-606.

West R (1990) Equality theory, marital rape and the promise of the 14th amendment. Florida Law Review; 42 (45): 45-79.

West R (2010) Sex, Law and Consent. In Wertheimer A and Miller W (eds). The ethics of consent: theory and practice. University Press: Oxford, pp 221-249.

Wriggins J (1983) Rape, racism and the law. Harvard Journal of Law and Gender; 6 (1): 103-141.

\section{Data availability}

The datasets generated and analysed during the current study are not publicly available due to the participants' confidentiality terms, but may be available from the corresponding author on reasonable request.

\section{Additional information}

Competing interests: The Authors declare no competing financial interests.

Reprints and permission information is available at http://www.palgrave-journals.com/ pal/authors/rights_and_permissions.html

How to cite this article: Ventura I (2016) "They never talk about a victim's feelings: according to criminal law, feelings are not facts"-Portuguese judicial narratives about sex crimes. Palgrave Communications. 2:160101 doi: 10.1057/palcomms.2016.101.

This work is licensed under a Creative Commons Attribution 4.0 International License. The images or other third party material in this article are included in the article's Creative Commons license, unless indicated otherwise in the credit line; if the material is not included under the Creative Commons license, users will need to obtain permission from the license holder to reproduce the material. To view a copy of this license, visit http://creativecommons.org/licenses/by/4.0/ 